University of Nebraska - Lincoln

DigitalCommons@University of Nebraska - Lincoln

\title{
On The Origin And Definition Of The Geologic Term "Laramie"
}

A. C. Veatch

US Geological Survey

Follow this and additional works at: https://digitalcommons.unl.edu/usgsstaffpub

Part of the Earth Sciences Commons

Veatch, A. C., "On The Origin And Definition Of The Geologic Term "Laramie"'" (1907). USGS Staff -Published Research. 500.

https://digitalcommons.unl.edu/usgsstaffpub/500

This Article is brought to you for free and open access by the US Geological Survey at DigitalCommons@University of Nebraska - Lincoln. It has been accepted for inclusion in USGS Staff -- Published Research by an authorized administrator of DigitalCommons@University of Nebraska - Lincoln. 


\title{
ON THE ORIGIN AND DEFINITION OF THE GEOLOGIC TERM "LARAMIE"»
}

\author{
A. C. VEATCH
}

\section{TABLE OF CONTENTS}

Introduction.

Present usage of the term "Laramie."

King's statement.

Boundaries of the Laramie Plains.

Hayden's investigations.

Hague's studies.

Cross's redefinition.

Summary and conclusions.

\section{INTRODUCTION}

Investigations of the United States Geological Survey during the summer of I906, covering the larger part of the Laramie exposures on the Laramie Plains, examined by the King and Hayden surveys, have revealed many new and important facts bearing on the Laramie problem.

By detailed areal surveys it was found: (I) that the lignitiferous series, which in the Laramie Plains lies between the Montana below and the Fort Union above, and has a maximum thickness of about I 2,500 feet, is divided about the middle by an unconformity; (2) that this unconformity is in the same stratigraphic plane and continuous with the unconformity which in the vicinity of Carbon and to the southeast separates all the Laramie beds studied by the Hayden and King parties from the underlying Cretaceous; (3) that the beds above the unconformity rest, often with great divergence of dip, on all the underlying beds down to and including the Dakota; (4) that the basal conglomerate, locally well developed at the horizon of the unconformity, while composed largely of materials derived from the underlying Cretaceous rocks, notably the Benton, contains pebbles and bowlders from the pre-Cambrian crystallines now exposed in

I Published by permission of Director of the U. S. Geological Survey. 
the hearts of the surrounding ranges. This unconformity thus involves the total thickness of the Cretaceous portion of the beds below the unconformity, and probably the whole sedimentary series of this region, or over 20,000 feet of strata.

The Laramie Plains section in brief is as follows:

GENERALIZED SECTION OF THE ROCKS OF THE WESTERN PART OF THE LARAMIE PLAINS IN CARBON COUNTY, WYOMING

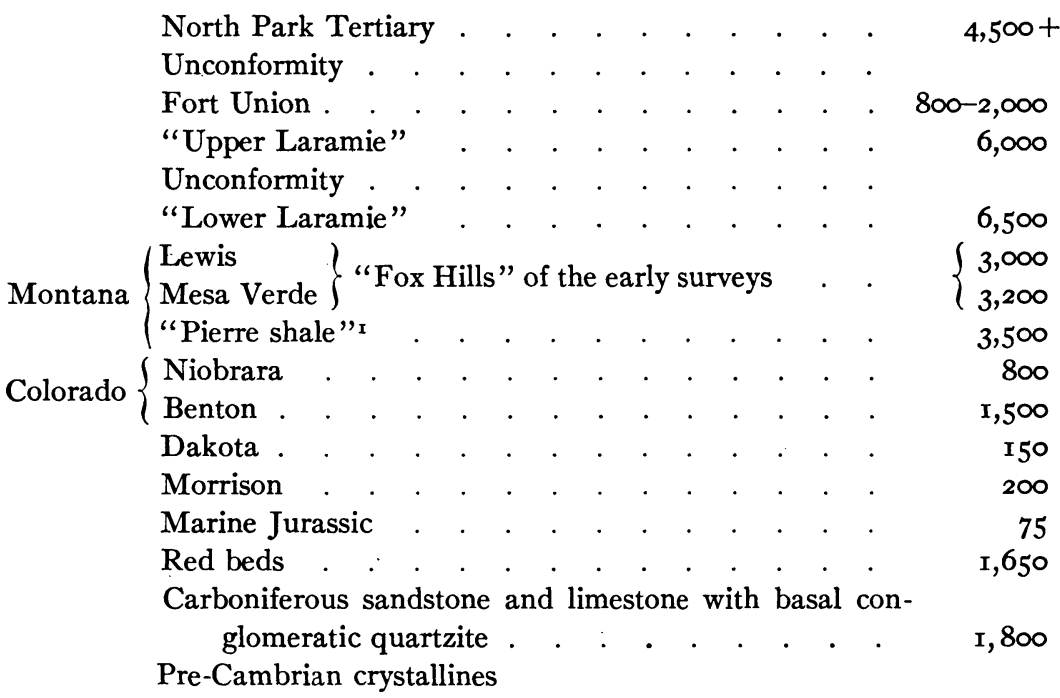

It may be said that in the areas examined by the Hayden and King parties, all of which were immediately along and south of the Union Pacific Railroad, the lower division is usually absent, the upper resting generally on one or another of the members of the Montana, but at one point extending over on to the Dakota. The large development of the division beneath the unconformity and above the Montana, corresponding to the "Lower Laramie" of literature, lies entirely north of the area they studied, and its existence was not known until the work of the past season.

I It is the belief of Dr. T. W. Stanton that the Mesa Verde and part of the Lewis belong to the Pierre, as that formation is developed east of the Rocky Mountains. A local name will therefore be applied to this lowest division of the Montana in this section. 


\section{PRESENT USAGE OF THE TERM "LARAMIE"}

The three principal usages of the term "Laramie" today are shown in the recent textbook of geology by Chamberlin and Salisbury. Here "Laramie series" is applied to all the beds between the Montana and Fort Union. Upper Laramie and Lower Laramie or "Laramie proper" are applied respectively to the beds above and below the great unconformity, first shown by Cross to exist in the Denver region, then found by Weed in western Montana, in 1905 found in southern Uinta County, Wyoming, by the writer, and traced northward by Dr. Schultz in I 906 to a point just south of Yellowstone National Park, and again found in 1906 , most strikingly developed, in Carbon County, Wyoming, in the western part of the Laramie Plains. The Lower Laramie has also been called "true Laramie," and sometimes simply Laramie. The complexness of the situation is excellently illustrated by the use of "Laramie" by Stanton and Knowlton in seven different combinations on a single page of their report, namely "Laramie series," "true Laramie," "so-called Laramie," "original Laramie," "typical Laramie," "the Laramie," "supposed true Laramie." I

Because of the frequent and necessary reference to the upper and lower divisions in the present discussion, the names "Upper Laramie" and "Lower Laramie" will be applied in this discussion in the sense used by Chamberlin and Salisbury, and in other geologic literature.

\section{KING'S STATEMENT}

A critical historical consideration of the origin of the word "Laramie," which may be expected to lead to some scientifically defensible conclusion regarding what the term can and cannot be properly used for, may very naturally begin with King's explanation in his Systematic Geology of the Exploration of the Fortieth Parallel. King here makes three important references to the subject, which because of their intimate bearing on this discussion are quoted at length:

Conformably overlying the Fox Hill group of Hayden is a considerable series of rocks over which a conflict of opinion now exists. These rocks Dr. Hayden has successively considered as Tertiary and as transitional between the Cretaceous

x "Stratigraphy and Paleontology of the Laramie and Later Formations in Wyoming," Bulletin of the Geological Society of America, Vol. VIII (I897), p. I28. 
and the Tertiary. They conformably overlie the Fox Hill of Meek and Hayden, and are developed throughout a large part of Wyoming, as well as upon the great plains east of the Rocky Mountains south of the forty-first parallel. That there might be no misunderstanding as to the stratigraphical position and nature of the rocks themselves, Dr. Hayden and I mutually agreed to know them hereafter as the Laramie group, and to leave their age for the present as debatable ground, each referring them to the horizon which the evidence seemed to him to warrant. $^{\mathrm{x}}$....

The great sandstone series of the Fox Hill is conformably overlain by a continuation of the sandstones, which attain a thickness of from 1,500 to 5,000 feet, varied very greatly in lithological character over different areas, but in general characterized by the frequent occurrence of workable beds of lignite and innumerable seams of carbonaceous clay. The fossil forms which are found in this series have led to a disagreement, which has now become historic, as to the age of the beds. They were at first, by Meek and Hayden, held to be distinctly Tertiary. That opinion has since been so modified as to lead those gentlemen to designate them as beds of transition. On the other hand, Dr. Le Conte, Professor Newberry, Professor Stevenson, and Major Powell have all committed themselves to the view advanced by me in Volume III of this series in 1870 , that the whole of the conformable series is Cretaceous. During the slow gathering of the evidence which shall finally turn the scale, I proposed to Dr. Hayden that we adopt a common name for the group, and that each should refer it to whatever age his data directed. Accordingly, as mentioned in the opening of this chapter, it was amicably agreed between us that this series should receive the group name of Laramie, and that it should be held to include that series of beds which conformably overlies the Fox Hill. ${ }^{2}$... . .

Here, with those who follow Hayden, the Cretaceous series comes to an end. Conformably over this lies the group which Hayden and I have agreed to call the Laramie, which is his Lignitic group, and is considered by him as a transition member between Cretaceous and Tertiary. There is no difference between us as to the conformity of the Laramie group with the underlying Fox Hill. It is simply a question of determination of age upon which we differ. ${ }^{3}$

It is evident from the above: (I) that Laramie was adopted as a name for the beds which Hayden called Lignitic in Wyoming and Colorado, ${ }^{4}$ and (2) that the beds so included were believed by both Hayden and King conformably to overlie the Fox Hills sandstone. Considered with other available data, it is unquestionably true that

report of the Geological Exploration of the Fortieth Parallel, Vol. I (I878), p. 298.

2 Ibid., p. 331. 3 Ibid., p. 348.

4 This is further shown by the following phrases on p. 333 of King's report: "The Laramie or Lignitic period," "Hayden's Lignitic (now the Laramie) series." 
both King and Hayden intended that the term should apply to the beds which occur between the Fox Hills and the Wasatch.

The consideration that the name was adopted as a substitute for Hayden's Lignitic suggests that the proper way to approach this somewhat involved subject is through the writings of Hayden. A number of collateral facts tend to strengthen the view that in a critical discussion of the origin and definition of Laramie the writings of Hayden are of prime importance. In the first place, King did not personally desire to investigate the region from Fort Bridger eastward, and only undertook it when the chief of engineers so directed. On January $23,187 \mathrm{I}$, he wrote the chief of engineers as follows:

The parties under the charge of Dr. F. V. Hayden, geologist of the Interior Department, and that led by Professor O. C. Marsh, of Yale College, have devoted the past summer to the geological explorations of those portions of Wyoming and Colorado which I had intended to cover next summer. . . . . I am convinced that what I could do would add but little to results they have obtained. We should without doubt fill up minor gaps in the structural relations of the plains, but on the whole it seems to me that there is not sufficient inducement to warrant our devoting our time and funds to a field from which the cream has already been taken.

In a letter to the chief of engineers, dated February 9, I87 I, he gave the exact limit of his previous work as follows:

In answer to the communication of Colonel J. B. Wheeler which I have just received, concerning the extent of the Green River included within my explorations, I have the honor to say that no part of that section is embraced in the work already done. Our eastern limit is 30 miles west of the river. If my present plans are carried out, I had not intended to continue that way.

On the direction of the chief of engineers the work was continued eastward, but King's personal efforts were almost wholly devoted to the territory to the west of Green River. In 187 I S. F. Emmons passed rapidly up Bitter Creek Valley, examining the country as far east as Washakie. In 1872 he spent ten days, June 20 to 30 , examining the immense territory west of the North Platte River, south of the Seminoe Mountains, and north of the Elk Mountains. ${ }^{I}$ The outcrops in the Laramie Plains were examined by Arnold Hague in the fall of 1872 . When King therefore agreed with Hayden on a

I King's manuscript letters to the chief of engineers, dated July 3, I872, and February $\mathrm{I} 7, \mathrm{r} 873$. 
name which should be a substitute for and equivalent of Hayden's Lignitic as used in Colorado and Wyoming, he necessarily relied upon Hayden's work on the Laramie Plains with the corroboration furnished by the work of Hague and such hasty examinations as he may have made personally when visiting Hague's party. It is therefore essential to take up first the work of Hayden, and to trace the natural growth and development of his knowledge which made "Laramie" an entirely natural and desirable term to Hayden.

\section{BOUNDARIES OF THE LARAMIE PLAINS}

Before following up the suggested clue afforded by the writings of Hayden, it may be well to outline the boundaries of the Laramie Plains as they were understood at the time of the adoption of the word "Laramie." On all the army maps ${ }^{1}$ of this region the Laramie Plains are shown as extending from the Front Range westward to the region of the North Platte River. In I87 I Professor Cyrus Thomas, of the Hayden Survey, gave the following definition of the Laramie Plains: ${ }^{2}$

This section is bounded on the east and northeast by the Black Hills, ${ }^{3}$ on the west by the West Rattlesnake Hills, ${ }^{4}$ and on the southwest by Medicine Bow Mountains. It is somewhat quadrangular in shape, its average length from southeast to northwest being about 90 miles, and average width from northeast to southwest about 75 miles, containing (exclusive of the surrounding mountains) a surface area of about $6,75^{\circ}$ square miles, or nearly $4,500,000$ acres. It is drained chiefly by the Medicine Bow and Laramie Rivers and their tributaries, both affluents of the North Platte, which also traverses the extreme western border. The Laramie, rising in the mountains at the southwest angle, flows along the eastern border to the northeast angle of the section, where it breaks through the Black Hills and joins the North Platte in the plains beyond. . The Medicine Bow, receiving affluents from each side, but principally from the south, flows through the western part of the section and joins the North Platte on the western border; which latter stream makes its exit at the northwest angle. . . . .

The southeast part, to which the name "Laramie Plains" is sometimes limited, is decidedly the best portion of the section, and contains much the largest propor-

I These were the general maps in common use by the Hayden and King parties.

2 Fourth Annual Preliminary Report, U. S. Geological Survey of Wyoming (being a Second Annual Report of Progress), (1871), pp. $220,22 \mathrm{I}$.

3 Now called the Laramie Hills or Front Range.

4 Now called the "Haystacks" and situated just west of the North Platte River in Carbon County, Wyo. 
tion of arable land. Counting from the head of the Laramie Valley to Rock Creek, it is about 70 miles long, with an average width of about 25 miles, giving an area of $1,75^{\circ}$ square miles.

Thus there appear to have been two usages for the term "Laramie Plains"- -one in common use on the army maps and, to a greater or less extent, among the people, as is shown in official reports of the surveyor general of Wyoming $;^{\mathrm{I}}$ and a second restricted to the portion east of Rock River (sometimes also given as Medicine Bow River). The term was not extended to the plains west of the natural western limit afforded by the West Rattlesnake Hills or Haystacks. Hayden used the term in both senses. In his report for r 868 he says: "In the Laramie Plains, along the line of the Union Pacific Railroad, extensive beds of cozl have been opened, and the coal is used for generating steam and for fuel on the cars.", ${ }_{2}$ This is clearly a reference to the mines at Carbon.

In 1869 he said, in speaking of a trip from Fort Sanders to Fort Fred Steele: "Our course was along the Overland Stage Road just at the base of the mountains, on the south side of the Laramie Plains, from 5 to 20 miles south of the Union Pacific Railroad line." 3

In his report for I870 Hayden used "Laramie Plains" both in the limited and in the broader sense. Thus the statement that the "entire surface of the plain east of the Medicine Bow forms one vast pasture ground" implies clearly that there are two portions of the plain, one east and one west of the Medicine Bow River. ${ }^{4}$

The statement that the Laramie Plains "is usually understood to extend westward almost to the Medicine Bow River" 5 is clearly the

I Annual Report of the Commissioner of the General Land Office for 1871, 1872, p. 27 I ; see also Fourth Annual Report, U.S. Geological Survey of Wyoming (187 I', p. 25 I.

2 Proceedings of the American Philosophical Society, Vol. X (1868), p. 467; [Second Annual Report, U. S. Geological Survey of the Territories, 1868] Report of the Commissioner of the General Land Office for 1868, 1868, p. 233; First, Second, and Third Annual Reports, U. S. Geological Survey of the Territories for 1867, 1868, and 1869, p. 80. This statement should be compared with the statement on p. 89 of the last report (p. 242 of the original Land Office report), where it is stated that the Laramie Plains are 60 miles from east to west. This width, when compared with Thomas' statement, places the western edge of the Laramie Plains near the North Platte River.

3 Proceedings of the American Philosophical Society, Vol. XI (1869), p. 34.

4 Fourth Annual Report, U. S. Geological Survey of Wyoming and Contiguous Territories (being a Second Annual Report of Progress), (187 I), p. 79.

5 Ibid., p. I 2 I. 
restricted usage, unless it is held that the expression "North Platte River" was really intended instead of Medicine Bow River-a view which is sustained by the width of 50 miles from east to west which is given for the plain, and by other expressions given in the context; while in the statement that the North Platte River cuts its "way through immense canyons between the North Park and the Laramie Plains," and again, "the Medicine Bow and the two Laramies . . . . take their rise in the elevated snow-capped mountains on the south side of the Laramie Plains," "the term is clearly used in its broader sense. In all of the geological references the term is used in its broader sense.

Hague, in speaking of the western limit of the Laramie Plains, says in 1878 :

To the northwest, however, the Plains are not entirely rimmed in, the open country stretching for a long distance without marked geographical boundary. For most purposes, however, it will be well to regard the western boundary of the Plain as limited by the Como Ridge just north of the Medicine Bow Range. . . . . As thus defined, the Laramie Plains measure at least 80 miles in length by about 30 miles in breadth. ${ }^{2}$

This is clearly the restricted usage, but it recognizes a broader usage. It is in this broader sense that the phrase "Laramie Plains" is used by the present writer.

\section{HAYDEN'S INVESTIGATIONS}

Hayden studied the exposures in the Laramie Plains in 1867 , I $868, \mathrm{I} 870$, and 1875 . In the fall of 1867 , after the completion of the field-work on the geology of Nebraska Territory, he passed over the Front Range into the Laramie Plains and proceeded along the Overland Stage Road as far west as the now famous Rock Creek locality. ${ }^{3}$ He then proceeded by way of the Overland Stage Road to South Bowlder Creek, a short distance north of Denver, thence northward

I Ibid.

${ }^{2}$ Geological Exploration of the Fortieth Parallel, Vol. II (1877 [1878]), p. 73.

3 American Journal of Science, Second Series, Vol. XLV (1868), pp. I0I, I02 (letter to J. D. Dana, dated Cheyenne City, Dakota Territory, October 31, 1867); ibid., pp. 199, 200, 204, 205; Final Report, U. S. Geological Survey of Nebraska (1872), pp. 46, 54, 55. Hayden states that the last report was printed without revision in exactly the same form, except for certain omissions, as it was transmitted to the commissioner of the General Land Office on March I, I 868 . 
to Cheyenne along the east base of the mountains. In this investigation he recognized in the Laramie Plains Cretaceous beds up to and including the Fox Hills, ${ }^{\mathrm{x}}$ and found that "at Rock Creek, about 40 miles west of the big Laramie River, the lignite beds overlap ${ }^{2}$ the Cretaceous." 3 He collected from these lignite beds "in the Laramie Plains . . . . two species of plants, a Populus and a Platanus, specifically identical with those found on the upper Missouri." This collection of plants was studied by Lesquereux ${ }^{5}$ and listed as from "Rock Creek, Laramie Plains." As knowledge of the flora progressed, Lesquereux referred this collection to the same horizon as the Carbon plant-beds, ${ }^{6}$ and in the light of present knowledge there can be no reasonable doubt that they came from the same formation. After his field-work of 1867 , Hayden announced the doctrine, entirely natural from his knowledge of and experience with the coal-bearing beds in the Dakotas, eastern Montana, and northeastern Wyoming, that all the coal-bearing beds of the Rocky Mountain region are younger than the Fox Hills. He thus included certain Upper Montana coal-bearing beds which in the region of Rock Creek directly underlie the Upper Laramie strata containing the plants referred to above.

In I868 Hayden, continuing the "Survey of the Territories," extended his investigations of the Laramie Plains. He proceeded from Fort Sanders along the Overland Stage Road as far as Pass Creek, and then turned north to Fort Steele. Returning to Fort Sanders, he proceeded to examine the geology along the line of the Union Pacific Railroad from Fort Sanders westward.7 In his account

I Final Report, Geological Survey of Nebraska (1872), p. 55.

2 From the usage of the word "overlap" through Hayden's writings, it is believed that he used the word as a synonym of "overlie," and not in its present technical geologic sense.

3 American Journal of Science, Second Series, Vol. XLV (1868), p. 205.

4 Ibid., p. 204; see also p. IOI; and Final Report, Geological Survey of Nebraska (I872), p. 55 .

5 American Journal of Science, Second Series, Vol. XLV (1868), p. 205; [Third Annual] Preliminary Field Report, U. S. Geological Survey of Colorado and New Mexico (r869), pp. 95, 96.

${ }^{6}$ Fifth Annual Report, U. S. Geological Survey of Montana for 1871, 1872, p. 306.

7 [Second Annual Report, U. S. Geological Survey of the Territories, embracing Wyoming] Report of the Commissioner of the General Land Office for 1868, 1868, pp. 
of this trip he describes the exposures along the Overland Stage Road, and among the beds which he studied, and then referred to the Lignitic, there are none which are now known to belong to the Lower Laramie, or the "true Laramie" of recent geologic literature. He states that he found "great quantities of deciduous leaves" (which "indicate the Tertiary age of the rocks, and also show that they jut far up close to the foothills of the mountains") in strata which are now known to be Upper Laramie and which in that immediate region rest unconformably on all beds down to the Dakota. The preponderance of evidence indicates that it was from this locality on the overland trail just west of Rock Creek that he obtained the leaves identified by Lesquereux as from "Rock Creek, Laramie Plains," which are clearly Upper Laramie. He also examined the strata and collected leaves from the Upper Laramie beds at a point just north of Medicine Bow stage station (now Elk Mountain post-office). The Upper Laramie beds at this point rest on the Lewis shales, which because of the coal-bearing character of the underlying Mesa Verde beds Hayden at this time included in his Tertiary.

Along the railroad he found only Cretaceous outcrops until he reached a point 5 miles east of Como, where he reports a sandstone "with fragments of stems and leaves," which he at first thought was probably lower Tertiary. ' Continuing, he says:

From a point about ro miles west' of Como to St. Mary's Station . . . . the Tertiary formations occupy the country with the peculiar sands and sandstone and clays, and numerous coal-beds. The most marked development of the coal-beds is at Carbon Station, about 80 miles west of Laramie Station. . . . . In the beds above and below the coal are thousands of impressions of deciduous leaves, as Populus, Platanus, Tilia, etc. Some of the layers of rocks 2 to 4 inches in thick-

242-49; reprinted in First, Second, and Third Annual Reports, U. S. Geological Survey of the Territories (1873), pp. 89-96; Proceedings of the American Philosophical Society, Vol. XI (1869), pp. 28-38, 54, 55.

I This sandstone is low in the Cretaceous, and on second thought Hayden referred it to the Cretaceous (Proceedings of the American Philosophical Society, Vol. XI [I 869], p. 370 '. He re-examined the locality in 1870 and again referred it to the Cretaceous.

2 In the original this reads "east," but when compared with the statement that the Cretaceous rocks continue to a point about 5 miles east of Como, and when considered in connection with the general lay of the country it undoubtedly should be "west." It is changed to "west" in the reports for 1870 ([Fourth Annual] Preliminary Report, U. S. Geological Survey of Wyoming [1871], p. 164). 
ness are wholly composed of these leaves in a good state of preservation, and so perfect are they that they could not have been transported any great distance. ${ }^{\mathrm{I}}$

The extreme western portion of the area described by Hayden in the above as occupied by the Tertiary-that is, the region in the immediate vicinity of St. Mary's station-is underlain by Lower Laramie strata, but along the railroad the beds are almost entirely covered by Quaternary débris. The beds actually studied by Hayden in this area, and upon which he based his opinion, are certainly wholly Upper Laramie.

In summarizing his results in a letter written from the field to the commissioner of the General Land Office, Hayden shows that he had already begun to suspect that his decision that all coal-bearing beds in this region are Tertiary is not. well founded. In the same letter he announces his unqualified belief that the Tertiary beds-that is, those yielding the plants at Carbon, Medicine Bow stage station, and Rock Creek-are unquestionably conformable with the Cretaceous. He says:

We have taken the position also that the coal-bearing beds of the Laramie Plains are of Tertiary age, although some marine fossils are found in strata connected with the coal. There may, be some thin seams of impure coal in the upper Cretaceous beds. . . . . I can find no want of conformity between the Tertiary and Cretaceous beds, and indeed so gradually and imperceptibly do the Cretaceous beds pass up into the Tertiary that $\mathrm{I}$ have not been able to determine the line of separation. ${ }^{2}$

In a review of the same subject before the American Philosophical Society on February I9, I869, Hayden clearly shows that he regards the Carbon locality as not only the most important locality in the Laramie Plains, but as the connecting link between the great Lignitic group of the Missouri River (which he then, because of the flora, regarded as Miocene) and the coal-bearing deposits of Wyoming. He says, in summarizing his geological observations at this time:

The Cretaceous formations occupy the country for 60 miles from Laramie City to Lake Como. Genuine Jurassic beds . . . . are here exposed for a short

I [Second Annual Report, U. S. Geological Survey of the Territories] Annual Report, Commissioner of the General Land Office for I868, 1868, p. 249; Proceedings of the American Philosophical Society, Vol. XI (1869), p. 37.

2 Annual Report, Commissioner of the General Land Office, for I868, I868, p. 253; First, Second, and Third Annual Reports, U. S. Geological Survey of the Territories ( 1873 ), p. Io०. 
distance. Cretaceous beds, mostly No. 2, appear again west of Como. Miocene coal-beds overlay the Cretaceous just before reaching Carbon Station, 80 miles west of Laramie. At Carbon, where they are exposed to view, impressions of fossil leaves occur in the greatest abundance. The species are few, and nearly all of them identical with those described by Dr. Newberry, from the Miocene Tertiary beds of the Upper Missouri. Some strata consist almost entirely of leaves, in a fair state of preservation, as if they had not been subjected to a great deal of drifting prior to deposition. Indeed the trees themselves must have grown near the spot, to shed their leaves in such great abundance, just as we find leaves accumulated now in muddy bottoms. Dr. Newberry has identified from this locality, Populus cuneata, Populus Nebrascensis, Platanus haydeni, and an undescribed species of Cornus. The Wyoming Coal Company's shaft, sunk at this station to reach the coal, has descended nearly 60 feet through a considerable thickness of bluish-black arenaceous clay, in rather thick layers, upon the surface of which are great quantities of Populus and Platanus. Very nearly the same species are described [found] throughout a great thickness of these Tertiary beds, and the evidence seems to be pretty clear that the vegetation was nearly uniform throughout the period of the deposition of the coal strata. ${ }^{\mathrm{I}}$

Although Hayden did not work in this region in 1869 , he referred to the area in his "Review of the Leading Groups" in his report for this year. In this account he definitely refers the beds on the Laramie Plains (and for the first time) to "the great lignite group," ${ }_{2}$ and indicates that in the region west of the Laramie Plains he considers it limited above by the Washakie group.

In I870 Hayden, starting at Cheyenne, traveled northward to the Platte River, and thence westward along the old emigrant road through Smith Pass to Fort Bridger. Returning, he followed the Overland Stage Road up Bitter Creek Valley through Bridger Pass to Laramie City, and then re-examined the geology along the line of the railroad west of that point. In the report for this year he still refers some of the Montana and older Cretaceous sandstones containing coal-beds to the Tertiary, but there is evidence of a growing suspicion that they may be Cretaceous. ${ }^{3}$ He even goes to far as to say: "The evidence seems to point to the Cretaceous age of the coal group

I Proceedings of the American Philosophical Society, Vol. XI (r 869), pp. 54-55.

2 "Along the line of the Union Pacific Railroad we find in the Laramie Plains a most extensive exhibition of the great lignite group." - [Third Annual] Preliminary Field Report, U. S. Geological Survey of Colorado and New Mexico (r869), p. 90.

3 [Fourth Annual] Preliminary Report, U. S. Geological Survey of Wyoming for 1870,1871 , p. I65. 
in Weber Valley." He strongly emphasizes in this report the importance of the Laramie Plains localities, particularly Carbon, in the determination of the question of the age of these beds. He certainly singles out Carbon as the one locality at which the age can be fixed, regarding the flora as there developed as the important connecting link between the coal-bearing beds of Wyoming and those of the Missouri River region. He says:

The most important coal-mines are located at Carbon. No shells have ever been observed in connection with the coals, but thousands of impressions of deciduous leaves are found. It is important to fix the age of the coal-beds in any one locality. So far as we can determine, the coal-beds of the Laramie Plains are of Eocene age, although the plants are more closely allied to those of the Miocene period in the Old World. ${ }^{2}$

So far as the Evanston coal-mines are concerned . . . . I discovered a magnificent series of fossil leaves, among which Dr. Newberry informed me he had detected species identical with those occurring in connection with the coal-beds of the Laramie Plains and on the upper Missouri. ${ }^{3}$

In 1872 Hayden directed Lesquereux to make explorations in Colorado and Wyoming with a special "view to positively ascertaining the age of the Lignitic formations, either from data obtainable in collecting or examining fossil vegetable remains or from any geological observations which I [he] should be able to make." 4 In this examination he visited Rock Creek and Carbon. At Rock Creek he failed to find the locality from which Hayden obtained his leaves, finding only outcrops yielding characteristic upper Cretaceous marine forms. ${ }^{5}$ He thus anticipated, as Hayden had before, and perhaps to a more complete degree, anticipated by the finding of Fox Hills sandstones on Rock Creek, ${ }^{6}$ the conclusions reached many years later by Drs. Stanton and Knowlton 7 at this locality. At Carbon he included with the Lignitic, because of the presence of the fucoid $\mathrm{Hel}$ emynites, which he then supposed to be characteristic of the Lignitic,

I U. S. Geological Survey Report, loc. cit, p. I67.

2 Ibid., p. I64. 3 Ibid., p. 167.

4 Sixth Annual Report, U. S. Geological Survey of the Territories for $187_{2}$, 1873 , p. 3 I 7 .

s Ibid., p. $33^{\circ}$.

${ }^{6}$ Bulletin of the Geological Society of America, Vol. VIII (1896), pp. 137-43.

7 [Fourth Annual] Preliminary Report, U. S. Geological Survey of Wyoming (r87r), p. 79 . 
but which is more abundant in the upper Montana,${ }^{\mathbf{x}}$ certain Cretaceous coal-bearing sandstones which are now known to be Mesa Verde. With this exception, Lesquereux studied only beds of Upper Laramie age, making large collections from the immediate vicinity of the mines. He studied and recognized the sea-beach character of the conglomeratic sandstones just west of Carbon, which are now recognized as the base of the Upper Laramie. This conglomeratic sandstone contains pebbles now known to have been derived from the underlying Cretaceous and older rocks, and indicates an immense unconformity. His report, in the light of present knowledge, is extremely suggestive. Thus he refers the beds at Carbon to the "upper Lignitic" and suggests the equivalence of the conglomeratic sandstone just mentioned with "that of the upper member of the Lignitic of Colorado" (possibly meaning beds since reported as the Arapahoe).

Two reports by Hayden, clearly written before the final adoption of the word "Laramie," complete the history of the development of his knowledge and belief in this critical period. In a "Brief History of the Lignitic Group"2 Hayden states that "the Lignitic group of the Northwest [is] believed to be continuous southward with the Colorado and Laramie beds." In this report Hayden finally acknowledges the presence of coal in beds of true Cretaceous age, saying:

One fruitful source of difference of opinion has been in the misunderstanding in regard to the different horizons of the coal strata of the West. That there are important coal-beds in rocks of well-defined Cretaceous age cannot be disputed, and $I$ have long since yielded that point. What we wish to show more clearly is that there exists in the West a distinct series of strata which we have called the Lignitic group, and that it is entirely separate paleontologically and geologically from a great group of strata in the lower Cretaceous, ${ }^{3}$ and perhaps extending down into the Jurassic, which contain a great number of thick and valuable beds of coal. It is not necessary to discuss the question whether the term Lignitic should be applied to either or both groups. I have used the term Lignitic for the upper

x Hayden recognized this in 1875 (Bulletin, U. S. Geological and Geographical Survey of the Territories, Vol. I [1876], p. 404), and it has since been abundantly proven.

2 Eighth Annual Report, U. S. Geological Survey of the Territories for 1874, 1876, pp. 19-27.

3 The phrase "lower Cretaceous" is not here used in the present technical sense (Lower Cretaceous or Comanche beds were unknown to Hayden) but rather in the sense of underlying. 
group without reference to the quality of the fuel simply to distinguish it from the other great group of older age, the age of which is not questioned. . . . . It is well known that $I$ have held with some tenacity the opininon that the coal formations of the West are of Tertiary age; and I still regard the Lignitic group proper as transitional or lower Eocene.

The name "Laramie beds" is used in the first of the above quotations in a simple geographic sense, but it clearly indicates what to Hayden was a most natural term. In the Hayden report for 1873 , published in 1874 , Marvine, in discussing the exposures in the vicinity of Denver and Golden, Colo., used the geographic name "Colorado Lignitic group," " with the suggestion "that the extended explorations of Hayden and others would seem to prove almost conclusively that the Colorado Lignitic group is the direct southern stratigraphical equivalent of the Fort Union group of the upper Missouri." But he adds the precautionary statement : "When all the facts are known, they may develop some new ideas as to geological transitions." The Colorado beds in the above clause from Hayden's History of the Lignitic Group are clearly the same as the "Colorado Lignitic group" of Marvine, and there was thus at this time two natural names for the Lignitic group as developed in Wyoming and Colorado-the Colorado group and the Laramie group. When Hayden and King agreed to use the term "Colorado group" as an appropriate name for the combined Fort Benton, Niobrara, and Pierre, " the term "Laramie group" was left as the natural and appropriate designation.

In "Notes on the Lignitic Group of Eastern Colorado and Portions of Wyoming," which appears to have been the last paper written by Hayden on this subject before the adoption of Laramie, he states that

throughout the Lignitic proper, that is the portion occurring above the Fox Hills group, I have never found any true nonconformity. That there may be in some places an interrupted sequence in the beds is quite possible. . . . That there have been many oscillations of the surface, that it has been alternately above and below water many times, may be inferred from the numerous coal-beds. In the aggregate, there could hardly have been any marked interruption in the sequence of the deposition, even up to the summits of the highest Tertiary, though between

I Seventh Annual Report, U. S. Geological and Geographical Survey of the Territories for 1873 , i874, p. 107.

${ }^{2}$ Report of the Geological Exploration of the Fortieth Parallel, Vol. I (1878), p. 298. 
the Lignitic group and the more modern Tertiaries, as the Washakie, Green River, and other fresh-water groups, there is at this time a true nonconformity. . . . . If we could look beneath the horizontal strata of the Washakie group between Separation and Bitter Creek, or under the Bridger and Green River groups along the immediate line of the railroad, we might find localities where the sequence of the beds is not interrupted, and yet, in the immediate vicinity of the mountainranges, as the Uintah, for example, the modern fresh-water Tertiaries rest unconformably on the older rocks. ${ }^{x}$

This clearly shows that in this region Hayden regarded the Lignitic as limited below by the Fox Hills and above by the Washakie (Wasatch or Vermilion Creek) group. That he had already begun to suspect the existence of a break at the base of the Laramie is suggested by the following statement:

It is evident that in many localities, and possibly throughout eastern Colorado, a considerable portion of the Upper Fox Hills group is wanting. Sometimes the Lignitic group is deposited on No. 4 or No. 3 Cretaceous. Therefore there is undoubtedly a conformable interrupted sequence; in other words, while the Lignitic group appears to conform to the underlying beds, there really are wanting hundreds, and perhaps thousands, of feet of strata which at some other locality in the West may exist. ${ }^{2}$

\section{HAGUE'S STUDIES}

Another line of evidence is perhaps needed to give the complete historical background necessary to reach a correct conclusion in this question of the origin and definition of the term "Laramie." There are a number of reasons for believing that not only was the term "Laramie," as has been shown, the most natural name for Hayden to suggest when asked by King for an appropriate term, ${ }^{3}$ but it was also the name which was independently suggested to King by Hague. ${ }^{4}$

I Bulletin, U. S. Geological and Geographical Survey of the Territories, Vol. I, No. 5 (January 8, I876), p. 4 Iо.

2 Ibid., p. 404 .

3 Dr. A. C. Peale has informed me that he has in his possession a letter from King to Hayden, bearing a date later than November I5, I875, requesting that he, Hayden, propose a name for the Lignitic.

4 Verbal statement by Mr. Hague to the author, corroborated by the use of the term "Laramie" on a map issued by the King Survey, November I5, I875. See American Journal of Science, Third Series, Vol. XI (1876), p. I6r; Bulletin, U. S. Geological Survey of the Territories, Vol. III (1877), p. I82; Bulletin No. 82, U. S. Geological Survey (I89i), p. I47. 
Mr. Hague studied the region of the Laramie Plains in the fall of 1872. At the Rock Creek locality he reports and maps only Fox Hills strata, ${ }^{1}$ although he states he did not see the coal openings reported by Hayden, near one of which typical Upper Laramie plants have since been found, ${ }^{2}$ thus confirming the early observations of Hayden. Carbon was therefore the only locality on the Laramie Plains where Hague recognized Laramie strata. The strata at this point which he refers to the Laramie are clearly Upper Laramie.

In opening the discussion of the Carbon locality, Hague says:

Geologically the place has also received considerable attention in examining the question of the age of the Wyoming coals. There would appear to be but little doubt that the beds belong to the Laramie division of the Cretaceous sandstone.

It would certainly have greatly simplified one point in the consideration of this greatly involved subject if Hague had said here, as he has since said in conversation, that the beds are called Laramie because of their exposure at this point on the Laramie Plains. It is unquestionably the only point on the Laramie Plains where the Laramie beds were recognized and critically studied by the King Survey, and King was too keenly alive to the absolute importance of a geographic origin for geologic names (the names being derived from type localities at which the beds were well exposed and could be unquestionably defined) to have permitted the adoption of, or even seriously considered, a term not definitely fixed in this way. His feeling in the matter is clearly shown by the fact that he refused to use the prior name "Wasatch" solely because at what he considered the type locality of Hayden, the Wasatch Mountains, the beds were not fully and typically exposed. He considered this sufficient reason to reject this name and to apply a new name, "Vermilion Creek group," taken from the locality where the beds were well exposed and could be fully defined. ${ }^{3}$ In the light of these facts, it is clear that the

I Report of the Geological Exploration of the Fortieth Parallel, Vol. II [1877 (1878)], pp. 86-87.

2 Bulletin of the Geological Society of America, Vol. VIII (I896), pp. I4I, I42. The field-work of 1906 practically connected this locality with that at Carbon and completely confirmed the provisional reference by Dr. Knowlton.

3 Report of the Geological Exploration of the Fortieth Parallel, Vol. I (I878), p. 354 . King's belief that the name "Wasatch" was taken from the Wasatch Mountains is shown by a careful consideration of Hayden's writings to have been unfounded. The type 
rhetorical doubt expressed in the above sentence from Hague's report relates solely to the point whether or not these beds were Cretaceous. No one has questioned or could question that they were Laramie, since they were the exposures which justified the use of the name. The question, as clearly shown by the preceding section and ensuing discussion, was solely the one of geologic age. Lesquereux, from large collections of plants at this point, had asserted that the beds were undoubtedly Miocene. Starting with this rhetorical question, Hague proceeds to "determine the true horizon of these beds," namely that they are Cretaceous, by "tracing out their relations with the great sandstone formation [Fox Hills] which forms all the higher ridges of the region," and by comparing "the strata with other similar localities." He then states that the "beds at Carbon occupy a broad, irregular-shaped basin, the rocks on the west, south, and east all dipping in toward the center, surrounding it completely on three sides." He reports that on the west the beds of Simpson Ridge may be traced "passing conformably under the level coal-bearing strata of the valley;" that on the east the same coal-bearing sandstones are underlain by beds preserving the same dip, and to the south the beds "appear to be perfectly conformable with the basin strata." In other words, in his opinion the conformability of these Laramie beds with the underlying strata at this point is completely demonstrated. ${ }^{x}$

locality, as shown by the description of Hayden, extends from Carter, Wyo., to the Narrows, on Weber River, 7 miles below Echo City, Utah. The name is derived from Wasatch Station on the Union Pacific Railroad in Summit County, Utah, situated about midway between Carter and The Narrows. In this section the beds are very fully and completely exposed. See in this connection Professional Paper No. 56, U. S. Geological Survey (1907), pp. 87, 88.

I Hague's conclusion is clearly based wholly on the exposures (I) on the east flank of Simpson Ridge immediately southwest of Carbon, and (2) those along the railroad just east of town. The basal sandstones of the Upper Laramie outcrop along the east flank of Simpson Ridge with so nearly the same strike as the "Fox Hills sandstones" of the ridge (which are really Mesa Verde and several thousand feet below the top of the Montana) that from the exposures at this point one would certainly not suspect an unconformity except from a very critical study of the source of some of the contained pebbles. Immediately north and south of these exposures there is, however, a very marked angular unconformity between the Upper Laramie and the underlying Cretaceous strata. At the point where Hague reported conformity the upper 2,000 feet of the Lewis and all of the Lower Laramie is wanting. A few miles to the south the same Upper Laramie beds rest on highly inclined rocks of Cretaceous age, down to and including the Dakota. East of Carbon, Hague fixed the base of the Laramie at 
Taking up then the consideration of Lesquereux's conclusions, he decides that the age of the deposits

rests either on the fossil plants which they contain or upon their stratigraphic position, and where such testimony disagrees it would seem that the latter must necessarily receive the greater weight. .... Professor Lesquereux, notwithstanding he feels so positive as to the Miocene age of the Carbon beds, does not hesitate to place them below the Green River series, giving them a position in relation to the latter horizon which few geologists will be disposed to dispute, and which the geological maps and sections accompanying this report conclusively prove. In the second chapter of this volume it will be shown that the Green River beds are undoubtedly of Eocene age, that they are . . . . underlaid by a heavy thickness of the Vermilion Creek series, also Eocene, and that the latter overlies unconformably beds occupying the same horizon as the Carbon formation, which we regard as of upper Cretaceous age.

\section{CROSS'S REDEFINITION}

Hayden and King clearly adopted the word "Laramie" for the beds between the marine Montana Cretaceous and Wasatch or Vermilion Creek Eocene. The next important advance in the knowledge of this subject resulted from the work of Cross and Eldridge in the Denver region. They found here that the Laramie as mapped by the Hayden Survey was broken by an immense unconformity, succeeded by a second one of minor importance.

Cross was thus confronted with the difficulty of determining whether the beds above the unconformity, or those below the unconformity, should most appropriately be called Laramie. After carefully considering the writings of King, and finding his statement that the Laramie included "that series of beds which conformably overlie the Fox Hills," Cross quite naturally decided that the term "Laramie" should be applied only to the beds below the unconformity. The fact that detailed work has now shown (I) that all the Laramie beds known on the Laramie Plains at the time of the adoption of the word "Laramie" are "Upper Laramie," (2) that, although they were believed to be entirely conformable with the underlying beds by all who had examined them, they are in fact separated from them by a great break, and hence that the statement of conformability in King's definition is without determinative value in this connection, because

the base of the Upper Laramie, and included in the Fox Hills beds of Lower Laramie age which are exposed at this point, thus absolutely and conclusively limiting the Laramie at this point to the Upper Laramie. 
based upon erroneous observations and conclusions, while proving that Cross's conclusion in this matter was incorrect, does not in any way detract from the great credit which is justly due him as the discoverer of this great break. Cross's error in this one particular of the restriction of the word "Laramie" to the lower beds was not due to his own observation, but to his acceptance of the work of others. This redefinition, instead of helping the already perplexed Laramie situation, but added one more complexity to it and resulted in the entirely incorrect and inappropriate application, to the Lower Laramie, of such terms as "Laramie proper," "original Laramie," "true Laramie."

The restriction of the term "Laramie" to the beds below the unconformity, based on Cross's studies in the Denver region, proves in its ultimate analysis to be an attempt to redefine a geologic term from the exposures and relations at a point almost 200 miles from the locality from which the geographic name was derived and at which the beds are most excellently exposed. This redefinition was based entirely on an abstract consideration of a statement based in part on erroneous observations, at a time when no critical re-examination had been made of the conditions in the region, whence the name was derived, and when nothing was known of the true relations in that area. We thus have the scientific anomaly of a geologic name derived from exposures in a certain region, all of which belong to one group of strata, redefined in a different region and applied to an entirely distinct group of beds. This is clearly indefensible and absolutely at variance with the fundamental principles of geologic nomenclature. It in effect gives a result which is no better than a lithologic term, and certainly not as appropriate. The whole case but emphasizes the absolute necessity of a geographic place origin for geologic names in order to finally guard against misinterpretations, incorrect statements, and conclusions by the authors of such names.

\section{SUMMARY AND CONCLUSIONS}

I. The name "Laramie" is derived from the Laramie Plains in eastern Wyoming. As commonly used in the early seventies, this included the plains region extending from the Front Range to and slightly beyond the North Platte River. 
2. The most important locality on the Laramie Plains at this time was Carbon. It was not only a noted paleontological locality, but was the most important coal-mining town on the Union Pacific Railroad at that time. It was the only locality on the Laramie Plains where the King Survey critically examined and distinctly delimited the Laramie beds. The Hayden Survey recognized Laramie strata at another point on the Laramie Plains, Rock Creek, but regarded the Carbon locality, including its southern extension containing the plants labeled from "Medicine Bow stage station," as affording better and more complete exposures.

3. It was the practice of the Hayden and King surveys to name formations and groups from localities where the beds were regarded as typically exposed. While King and Hayden did not always definitely state that a name was derived from a certain locality, the source of the name can in all cases be completely inferred from the context. Thus King used Green River, Bridger, Uinta, Truckee, and other names without saying the name was derived from such and such a locality, while he distinctly states the source of Vermilion Creek, Weber, and other names. King's strong feeling in this matter of a type locality is shown by the fact that he refused to use the prior name "Wasatch" and adopted the new name "Vermilion Creek" simply because at what he considered Hayden's type locality the beds were not completely and typically exposed. The state of feeling at this time is further shown by the fact that the name "Laramie" was proposed and adopted as an exact synonym of Hayden's "Lignitic" as defined by him in Wyoming and Colorado. If merely a general term without a type locality was desired, the term "Lignitic" would have served all purposes. The change was clearly based on a recognition of the necessity of having a geographic type locality. From the above facts it follows irresistibly that the type locality of the Laramie is Carbon, on the Laramie Plains.

4. A critical consideration of investigations of Hayden and King parties in this region shows that the actual Laramie exposures studied by them are separated from the Cretaceous by an unconformity of great magnitude. At Carbon Hague particularly and minutely included only the beds above the break. Both Hayden and Hague regarded these beds as entirely conformable with those beneath; 
hence the statement by King that the Laramie beds are those which conformably overlie the Fox Hills, while correct according to the existing knowledge, is not correct at the type locality, and therefore without determinative value in this connection. It but illustrates anew the absolute necessity of a type locality to afford means of finally and conclusively correcting any inaccurate statements or conclusions of the author or authors of a geologic name. Strictly considered, the term "Laramie" therefore can appropriately be applied only to the beds above the great unconformity and-fixing an upper limit in part from our present knowledge-below the Fort Union. ${ }^{x}$

5. The attempt to redefine the term "Laramie" from the exposures in the Denver region, some 200 miles from the type locality, is therefore not defensible. It results in the scientific anomaly of applying the term "Laramie" to a series of beds entirely distinct from those at the type locality on which the name was based. It completely robs the name of all geographical significance, and gives to it even less meaning or appropriateness than a mere lithologic term such as "Lignitic."

6. While strictly speaking the name."Laramie" can be appropriately applied only to the upper beds (Upper Laramie), and it cannot with any propriety be restricted to the lower beds (Lower Laramie), the consideration that it was proposed for the beds between the Wasatch and the marine Montana Cretaceous, and has been most commonly and extensively used in this broad sense, has led to the suggestion that the retention of the name in this original sense will cause the least confusion, and that it therefore might be expedient to define the Laramie as that series of beds occurring between the marine Montana Cretaceous and the Fort Union.

I At Evanston there are several reasons for believing that the base of the Wasatch of Hayden contains representatives of the Fort Union, Puerco, and Terrejon. Between the Laramie and the Coryphodon-bearing Wasatch are some 4,000 feet of strata separated from the Coryphodon-bearing beds by an unconformity. At Black Buttes beds now known to be Fort Union (Knowlton, Bulletin of the Geological Society of America, Vol. VIII [1896], p. I45) were referred by King to the Vermilion Creek. It therefore seems not only logical, but in accord with the original usage, to define the upper limit of the Laramie as the Fort Union. The Washakie beds which Hayden regarded as, in this region, limiting the Lignitic above (Third Annual Report, U. S. Geological Survey, Colorado, New Mexico, 1869, p. 90) and which were included by King in his Vermilion Creek, are the beds from which Knowlton reports distinctive Fort Union plants at Black Buttes. 
In connection with this suggestion of expediency, it should be pointed out that the continued use of this term in the "catchall" sense is wholly at variance with the abundance of strong and wholly logical reasons for the restriction of the term "Laramie" to the "Upper Laramie" shown by the historical considerations already presented. If the point of confusion is regarded as one of great importance, it might be worth while considering the entire abandonment of the term "Laramie."

In either case a new name is required for the beds here referred to as Lower Laramie. Many considerations suggest that this name should come from the region of the Laramie Plains. This would be historically appropriate in many ways, and would result in placing the type locality of both the upper and the lower portions of the beds which have been called Laramie in the broad sense, in the same section. There are reasons for believing that the enormous development of Lower Laramie beds in the western part of the Laramie Plains near the mouth of the Medicine Bow River, or, as it is more commonly called by the local people, "The Bow," where there is relatively very little evidence of a break between the upper and lower beds, more completely represents the Laramie deposition than at any other point now known. These considerations make the "Bow formation" or "group" a very appropriate designation for these lower beds. On the other hand, the fact that the region of Golden has been made classic in connection with the "Laramie problem" by the studies of Cross, Eldridge, Knowlton, and others, raises the question whether the name "Golden formation" or "group" might not be a more appropriate name.

The discovery of this great unconformity at all points that have been critically examined over an area I,ooo miles north and south and 250 miles east and west, the fact that it occurs on both the east and west sides of the Front Range of the Rocky Mountains, and its great magnitude, all make it one of the important mile-posts in the geologic history of western North America. All these considerations suggest anew the first conclusion of Cross in the Denver region that this unconformity marks the dividing line between the Cretaceous and Eocene in this region. On this basis the arrangement of groups immediately above and below the great break would be as follows: 


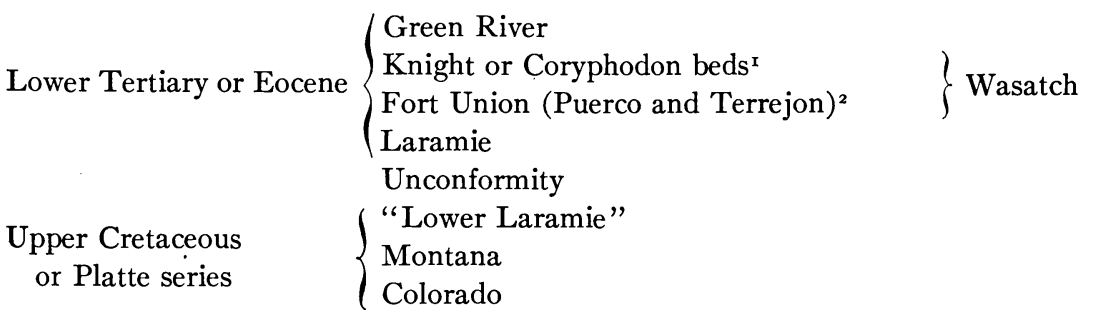

I The name "Knight" has been proposed for the upper part of the Wasatch containing Coryphodon remains. It is taken from Knight Station, a point near the locality where fossils belonging to this genus were first found in North America, and where the typical upper Wasatch is extremely well developed. Certain considerations suggest that the Knight formation may be an exact synonym of King's Vermilion Creek formation, but as the writer has not had the opportunity to examine King's type section he has proposed the provisional name "Knight" pending a study of the Vermilion Creek section. See Professional Paper 56, 1907, pp. 87-89, 92-96.

2 In the Evanston section, between the beds belonging to the Laramie (Carbon) group and the Coryphodon-bearing Wasatch, are 4,000 feet of strata which have the stratigraphic position of the Fort Union and Puerco. These are here separated from the Coryphodon-bearing portion of the Wasatch by an unconformity of much less magnitude and importance than that at the base of the Laramie (Carbon) beds. 